\title{
Adenosine 5'-Tetraphosphate and Adenosine 5'-Pentaphosphate Are Synthesized by Yeast Acetyl Coenzyme A Synthetase $\dagger$
}

\author{
ANDRZEJ GURANOWSKI, ${ }^{\ddagger}$ MARÍA ANTONIA GÜNTHER SILLERO, AND ANTONIO SILLERO* \\ Departamento de Bioquímica, Instituto de Investigaciones Biomédicas del Consejo Superior de Investigaciones \\ Científicas, Facultad de Medicina, Universidad Autónoma de Madrid, 28029 Madrid, Spain
}

Received 4 November 1993/Accepted 11 March 1994

\begin{abstract}
Yeast (Saccharomyces cerevisiae) acetyl coenzyme A (CoA) synthetase (EC 6.2.1.1) catalyzes the synthesis of adenosine 5 '-tetraphosphate $\left(p_{4} A\right)$ and adenosine $5^{\prime}$-pentaphosphate $\left(p_{5} A\right)$ from $A T P$ and tri- or tetrapolyphosphate $\left(P_{3}\right.$ or $\left.P_{4}\right)$, with relative velocities of 7:1, respectively. Of 12 nucleotides tested as potential donors of nucleotidyl moiety, only ATP, adenosine-5' $-O$-[3-thiotriphosphate], and acetyl-AMP were substrates, with relative velocities of 100,62 , and 80 , respectively. The $K_{m}$ values for ATP, $P_{3}$, and acetyl-AMP were $0.16,4.7$, and $1.8 \mathrm{mM}$, respectively. The synthesis of $p_{4} A$ could proceed in the absence of exogenous acetate but was stimulated twofold by acetate, with an apparent $K_{m}$ value of $0.065 \mathrm{mM}$. CoA did not participate in the synthesis of $p_{4} A\left(p_{5} A\right)$ and inhibited the reaction (50\% inhibitory concentration of $0.015 \mathrm{mM}$ ). At pH 6.3, which was optimum for formation of $p_{4} A\left(p_{5} A\right)$, the rate of acetyl-CoA synthesis $\left(1.84 \mu \mathrm{mol} \mathrm{mg}^{-1} \mathrm{~min}^{-1}\right.$ ) was 245 times faster than the rate of synthesis of $p_{4} A$ measured in the presence of acetate. The known formation of $p_{4} A\left(p_{5} A\right)$ in yeast sporulation and the role of acetate may therefore be related to acetyl-CoA synthetase.
\end{abstract}

Adenosine 5'-tetraphosphate $\left(\mathrm{p}_{4} \mathrm{~A}\right)$ and adenosine 5'-pentaphosphate $\left(\mathrm{p}_{5} \mathrm{~A}\right)$ were detected as contaminants of adenosine $5^{\prime}$-triphosphate preparations $(21,27)$, and $\mathrm{p}_{4} \mathrm{~A}$ was shown to be present in muscle $(16,33)$, liver $(38)$, and yeast (Saccharomyces cerevisiae) spores (9). The physiological role of nucleoside 5 '-tetraphosphates $\left(\mathrm{p}_{4} \mathrm{~N}\right)$ is largely unknown. Adenosine-, guanosine-, and uridine-tetraphosphates $\left(\mathrm{p}_{4} \mathrm{~A}, \mathrm{p}_{4} \mathrm{G}\right.$, and $\mathrm{p}_{4} \mathrm{U}$ ) are strong competitive inhibitors (nanomolar $K_{i}$ values) of asymmetrical dinucleoside tetraphosphatase (EC 3.6 1.17) $(15,17,24,36)$, an enzyme cleaving dinucleoside tetraphosphates to the corresponding nucleoside tri- and monophosphates. Since $\mathrm{Ap}_{4} \mathrm{~A}$ may be important in metabolic regulation (for a review, see reference 23), changes in the level of $p_{4} \mathrm{~N}$ could modulate its concentration and physiological effect. Other enzymes known to be inhibited (micromolar $K_{i}$ values) by $\mathrm{p}_{4} \mathrm{~N}$ are the soluble guanylate cyclase (EC 4.6.1.2) (8) and phosphodiesterase I and nucleotide pyrophosphatase (EC 3.1.4.1 and EC 3.6.1.9) from rat liver (2).

The level of $\mathrm{p}_{4} \mathrm{~A}$ depends on its rate of synthesis and degradation. A specific enzyme (EC 3.6.1.14) which hydrolyzes $\mathrm{p}_{4} \mathrm{~A}$ to ATP and $P_{i}$ exists in muscle (32), and the following enzymes have been reported to synthesize $p_{4} N$ : aminoacyltRNA synthetases and, particularly, the lysyl-tRNA synthetase (EC 6.1.1.6), which catalyzes the synthesis of $\mathrm{p}_{4} \mathrm{~A}$ from lysine, ATP, and pentasodium tripolyphosphate $\left(\mathrm{P}_{3}\right)(37)$; yeast phosphoglycerate kinase (EC 2.7.2.3), which forms $\mathrm{p}_{4} \mathrm{~A}$ (33) and $\mathrm{p}_{4} \mathrm{G}$ (6) from 1,3-bis-phosphoglycerate and ATP or GTP, respectively; adenylate kinase (EC 2.7.4.3), which was shown to transfer phosphate from ADP to ATP (14); a mutated Escherichia coli succinyl-coenzyme A (CoA) synthetase (EC 6.2.1.5) that was unable to catalyze the overall reaction (i.e., the synthesis of succinyl-CoA from ATP, succinate, and CoA) but

\footnotetext{
* Corresponding author. Mailing address: Departamento de Bioquímica, Facultad de Medicina, Universidad Autónoma de Madrid, Arzobispo Morcillo, 4, 28029 Madrid, Spain. Phone: 1-3975413. Fax: 1-3150075. Electronic mail address: ASillero@mvax.fmed.uam.es.

${ }^{+}$Dedicated to Professor Severo Ochoa, in memoriam.

‡ Present address: Katedra Biochemii, Akademia Rolnicza, ul. Wolynska 35, Poznan, Poland.
}

could synthesize $\mathrm{p}_{4} \mathrm{~A}$ from ATP through phosphorylation of the enzyme and transfer of the phosphate moiety from the enzyme-phosphate complex to ATP (19); and, finally, firefly luciferase (EC 1.13.12.7), which catalyzes the synthesis of $p_{4} A$ or $\mathrm{p}_{5} \mathrm{~A}$ by using luciferin, ATP, and $\mathrm{P}_{3}$ or hexaammonium tetraphosphate $\left(P_{4}\right)$, respectively $(25)$.

Because of the similarities between the reactions catalyzed by aminoacyl-tRNA synthetases, luciferase, and acyl-CoA synthetases $(7,22,25,31)$, we checked whether yeast acetyl-CoA synthetase (EC 6.2.1.1) could also catalyze synthesis of $p_{4} A$ from ATP and $\mathrm{P}_{3}$. Here, we describe the experimental conditions for the synthesis of both $\mathrm{p}_{4} \mathrm{~A}$ and $\mathrm{p}_{5} \mathrm{~A}$ by acetyl-CoA synthetase.

\section{MATERIALS AND METHODS}

Three commercial preparations of yeast acetyl-CoA synthetase were used: lot 89F8180 from Sigma (catalog no. A-5269) and two batches of a lyophilized synthetase, lot 127F0650 from Sigma (catalog no. A-1765) and lot 11496526-29 from Boehringer Mannheim GmbH (catalog no. 161675). $\mathrm{p}_{4} \mathrm{~A}$-degrading activity was undetectable in those synthetase preparations. As auxiliary enzymes, inorganic pyrophosphatase from yeast cells (catalog no. 108987), alkaline phosphatase from calf intestine (catalog no. 108138) (both purchased from Boehringer), and potato apyrase from Sigma (catalog no. A-6132) were used. All of the enzymes were solubilized and/or diluted before use in 25 mM HEPES ( $N$-2-hydroxyethylpiperazine- $N$ '-2-ethanesulfonic acid)-KOH buffer (pH 7.6) containing $5 \%$ glycerol, $0.1 \mathrm{mM}$ dithiothreitol, and $1 \mathrm{mg}$ of bovine serum albumin per $\mathrm{ml}$.

Adenosine -5'-O-[1-thiotriphosphate] $S$-isomer (ATP $\alpha \mathrm{S})$ and adenosine-5'-O-[3-thiotriphosphate] (ATP $\gamma \mathrm{S})$ were from Boehringer Mannheim GmbH. Adenosine $5^{\prime}-(\alpha, \beta-$-methylenetriphosphate) $\left(\mathrm{ppCH}_{2} \mathrm{pA}\right)$, adenosine $5^{\prime}-(\beta, \gamma-$ methylenetriphosphate) $\left(\mathrm{pCH}_{2} \mathrm{ppA}\right)$, adenosine $N^{1}$-oxide $5^{\prime}$-triphosphate, adenine $9-\beta$-D-arabinoside 5 '-triphosphate, and other nucleotides were from Sigma. Acetyl-AMP was synthesized as described earlier (10). $\mathrm{P}_{3}, \mathrm{P}_{4}$, and sodium phosphate glass with a chain length of $j \pm 2 \mathrm{P}$ were from Sigma (catalog no. T5633, T5758, and S5878, respectively). Buffers, salts, and organic 
solvents were of analytical grade. Labeled $\left[2,8-{ }^{3} \mathrm{H}\right]$ adenosine 5 '-triphosphate (catalog no. TRK.622 [42 Ci/mmol]) was from Amersham International plc, and $\left[{ }^{32} \mathrm{P}\right]$ tetrasodium pyrophosphate (catalog no. NEX 019 [ $20 \mathrm{mCi} / \mathrm{ml}]$ ) was from Dupont de Nemours GmbH, NEN. Enzyme assays are described in the legend to Fig. 1.

\section{RESULTS AND DISCUSSION}

In Fig. 1, a reaction mixture containing ATP, $\mathrm{MgCl}_{2}$, acetate, inorganic pyrophosphatase and acetyl-CoA synthetase is shown to accumulate $p_{4} A$, dependent on addition of $P_{3}$, or at a lower rate, $p_{5} A$, dependent on $P_{4}$. The reaction could be monitored either by thin-layer chromatography (TLC) (Fig. 1A) or high-performance liquid chromatography (HPLC) (Fig. 1B). The identity of $p_{4} A$ and $p_{5} A$ was established by comigration with standards, UV spectra identical with those of ATP, and sensitivity to alkaline phosphatase (Fig. 1C) and apyrase (data not shown). Smaller amounts of $A_{5} A$ (in the presence of $P_{3}$ ) and traces of $A p_{6} A$ (in the presence of $P_{4}$ ) and $A p_{4} A$ were also formed and similarly identified (Fig. 1B).

Modifying the standard incubation mixture by adding 100 mM MES (morpholineethanesulfonic acid), HEPES, and CHES (2-[ $N$-cyclohexylamino]ethanesulfonic acid) buffers covering the $\mathrm{pH}$ range from 5.1 to $9.5\left(\left[{ }^{3} \mathrm{H}\right] \mathrm{ATP}\right.$ and TLC method) showed a $\mathrm{pH}$ optimum for $\mathrm{p}_{4} \mathrm{~A}$ synthesis between 6 and 6.5 (MES-KOH buffer), with half-maximum activity at $\mathrm{pH}$ 5.2 and 7.4 and no synthesis observed above $\mathrm{pH}$ 8. Dependence on divalent cations is shown in Fig. 2.

The following compounds were tested at $3 \mathrm{mM}$ as potential donors of a nucleotidyl moiety onto $\mathrm{P}_{3}$ by using the (nonradioactive) HPLC assay method: ADP, ATP, dATP, ATP $\alpha S$ and $\mathrm{ATP} \gamma \mathrm{S}, \mathrm{ppCH}_{2} \mathrm{pA}, \mathrm{pCH}_{2} \mathrm{ppA}$, adenosine $N^{1}$-oxide $5^{\prime}$ triphosphate, adenine 9- $\beta$-D-arabinoside $5^{\prime}$-triphosphate (araATP), CTP, GTP, UTP, and acetyl-AMP. Only ATP, ATP $\gamma$ S, and acetyl-AMP were active, relative rates of $\mathrm{p}_{4} \mathrm{~A}$ synthesis being 100,62 , and 80 , respectively. Using the $\left[{ }^{3} \mathrm{H}\right] \mathrm{ATP}$ assay with TLC, rates with $P_{3}$ and $P_{4}$ were 7.5 and $1.0 \mathrm{nmol} \mathrm{mg}^{-1}$ $\min ^{-1}$, respectively; $\mathrm{P}_{5}$, even with $24 \mathrm{~h}$ of incubation, was not identified as a substrate. The rates of acetyl-CoA formation (in the presence of $5 \mathrm{mM}$ acetate and $5 \mathrm{mM} \mathrm{CoA}$ ) at $\mathrm{pH} 6.3$ and 7.5 (pH optimum of the reaction) were, respectively, 1.84 and $7.4 \mathrm{nmol} \mathrm{mg}^{-1} \mathrm{~min}^{-1}$. The ATP-PP ${ }_{\mathrm{i}}$ exchange reaction, using $2 \mathrm{mM}\left[{ }^{32} \mathrm{P}\right]$ pyrophosphate, $(1 \mathrm{pmol}$ is $112 \mathrm{cpm}$ ) (in the absence of pyrophosphatase), gave a rate of $0.72 \mu \mathrm{mol} \mathrm{mg}^{-1} \mathrm{~min}^{-1}$ in the presence of $1 \mathrm{mM}$ acetate and about half that value in the absence of added acetate.

For $\mathrm{p}_{4} \mathrm{~A}$ synthesis the $K_{m}$ value for ATP was $0.16 \mathrm{mM}$; a range of $\left[{ }^{3} \mathrm{H}\right] \mathrm{ATP}$ from $0.15 \mathrm{mM}$ to $2.4 \mathrm{mM}$ was used, with TLC determination of $\mathrm{p}_{4} \mathrm{~A}$. The $K_{m}$ for $\mathrm{P}_{3}$ was $4.7 \mathrm{mM}$, employing the same assay with $3 \mathrm{mM}\left[{ }^{3} \mathrm{H}\right] \mathrm{ATP}$ and 0.3 to 5 $\mathrm{mM} \mathrm{P}$. The $K_{m}$ for acetyl-AMP, was $1.8 \mathrm{mM}$; a range of 0.15 to $2.4 \mathrm{mM}$ acetyl-AMP was used along with HPLC determination of $\mathrm{p}_{4} \mathrm{~A}$.

$\mathrm{p}_{4} \mathrm{~A}$ synthesis occurred in the absence of added acetate, but the rate was increased twofold in the presence of $0.5 \mathrm{mM}$ acetate with half-stimulation at $0.065 \mathrm{mM}$. The possibility that the enzyme preparation contributed acetate was apparently excluded by the lack of effect of addition of preheated enzyme solution. No effect was observed for formate or propionate. Added CoA itself was inhibitory to the standard reaction ( $\left[{ }^{3} \mathrm{H}\right] \mathrm{ATP}$, TLC method) with a $50 \%$ inhibitory concentration of $0.015 \mathrm{mM}$, and such inhibition was prevented by inclusion of $0.5 \mathrm{mM}$ acetate, showing that acetyl-CoA is not inhibitory.

We have recently suggested that enzymes (mainly synthetases and some transferases) which catalyze the transfer of a nucleotidyl moiety via nucleotidyl-containing intermediates and release of $\mathrm{PP}_{\mathrm{i}}$, may produce dinucleoside polyphosphates (7). Aminoacyl-tRNA synthetases $(26,37)$ and luciferase (7, $25,31)$ are examples of this type of enzymes known to catalyze the synthesis of nucleoside 5'-polyphosphates $(n>3)$ and diadenosine tetraphosphate. Acetyl-CoA synthetase is another enzyme theoretically able to catalyze the synthesis of nucleoside 5'-polyphosphates $(n>3)$ or $\mathrm{Ap}_{4} \mathrm{~A}(7)$. The results presented in this paper arose from the observation made very recently with firefly luciferase (25) that the enzyme can catalyze the transfer of the adenylyl moiety from the enzymeluciferin-AMP complex onto various polyphosphates. The formation of $p_{4} A$ or $p_{5} A$ with acetyl-CoA synthetase might analogously involve $\mathrm{P}_{3}$ or $\mathrm{P}_{4}$ as the acceptor of the adenylyl moiety of the enzyme-acetyl-AMP complex as follows:

enzyme-acetyl-AMP $+\mathrm{P}_{n} \leftrightarrow \mathrm{P}_{n+1} \mathrm{~A}+$ acetate + enzyme (reaction 1)

An alternative mechanism, in view of the apparent absence of involvement of acetate in the reaction, would be

$$
\begin{array}{cc}
\text { enzyme }+\mathrm{ATP} \leftrightarrow \text { enzyme-AMP }+\mathrm{PP}_{\mathrm{i}} & \text { (reaction 2) } \\
\text { enzyme-AMP }+\mathrm{P}_{3} \leftrightarrow \mathrm{p}_{4} \mathrm{~A}+\text { enzyme } & \text { (reaction 3) }
\end{array}
$$

In contrast to various aminoacyl-tRNA synthetases $(26,37)$ and firefly luciferase $(7,25,31)$, which require the cognate amino acid and luciferin, respectively, to form an enzyme-XAMP complex (in which $\mathrm{X}$ stands for an organic acid able to form an anhydride bond with AMP), the yeast acetyl-CoA synthetase can catalyze the transfer of adenylate coming from ATP to a polyphosphate without forming, apparently, an acyl-AMP intermediate. In addition to that, however, the yeast enzyme can use the specific acyl-AMP intermediate acetylAMP as a source of adenylate.

Although it is not the object of this work to elucidate the mechanism of the synthesis of $\mathrm{p}_{4} \mathrm{~A}$, whether it goes through reaction 1 or reaction 2 , (implying the formation of enzymeacetyl-AMP or enzyme-AMP intermediates, respectively), some comments could be raised on this point. Contradictory reports concerning the acetate dependence or independence of the ATP-PP $\mathrm{P}_{\mathrm{i}}$ exchange date from the early fifties (compare references 12 and 20 with reference 1). Variability in the results has been ascribed, among other causes, to important mechanistic differences between the members of this type of enzymes (acyl-CoA synthetases included), to the occurrence of a hypothetical factor required for the formation of enzymeAMP complex, which could be lost in the process of the enzyme purification, and to the presence of the contaminant acetate (18). Direct interaction of ATP with the enzyme is also supported by the stabilizing effect exerted by that nucleotide on the acetyl-CoA synthetase through an unknown mechanism $(5,29)$. Since the molecular weights obtained in the presence and absence of ATP are identical (29), the possibility that adenylylation of the synthetase by ATP contributes to its stability should also be considered. Also, because the enzyme has an $\alpha_{2}$ structure (5) and, as is shown in this study, the exogenous acetate doubles the rate of $\mathrm{p}_{4} \mathrm{~A}$ synthesis observed in the absence of acetate, it seems plausible that each subunit of the synthetase participates in that reaction in a different manner-according to reaction 1 or 3 . The existence of two interacting substrate sites for ATP was proposed earlier for the acetyl-CoA synthetase from Methanothrix soehngenii (11).

As shown, tripolyphosphate was a very good adenylyl acceptor. In contrast to the findings with luciferase, which employs polyphosphate chains of up to 20 phosphate residues, yeast acetyl-CoA synthetase was not able to produce even $p_{6} A$, from ATP and $P_{5}$. Also, unlike the reaction with luciferase, the 

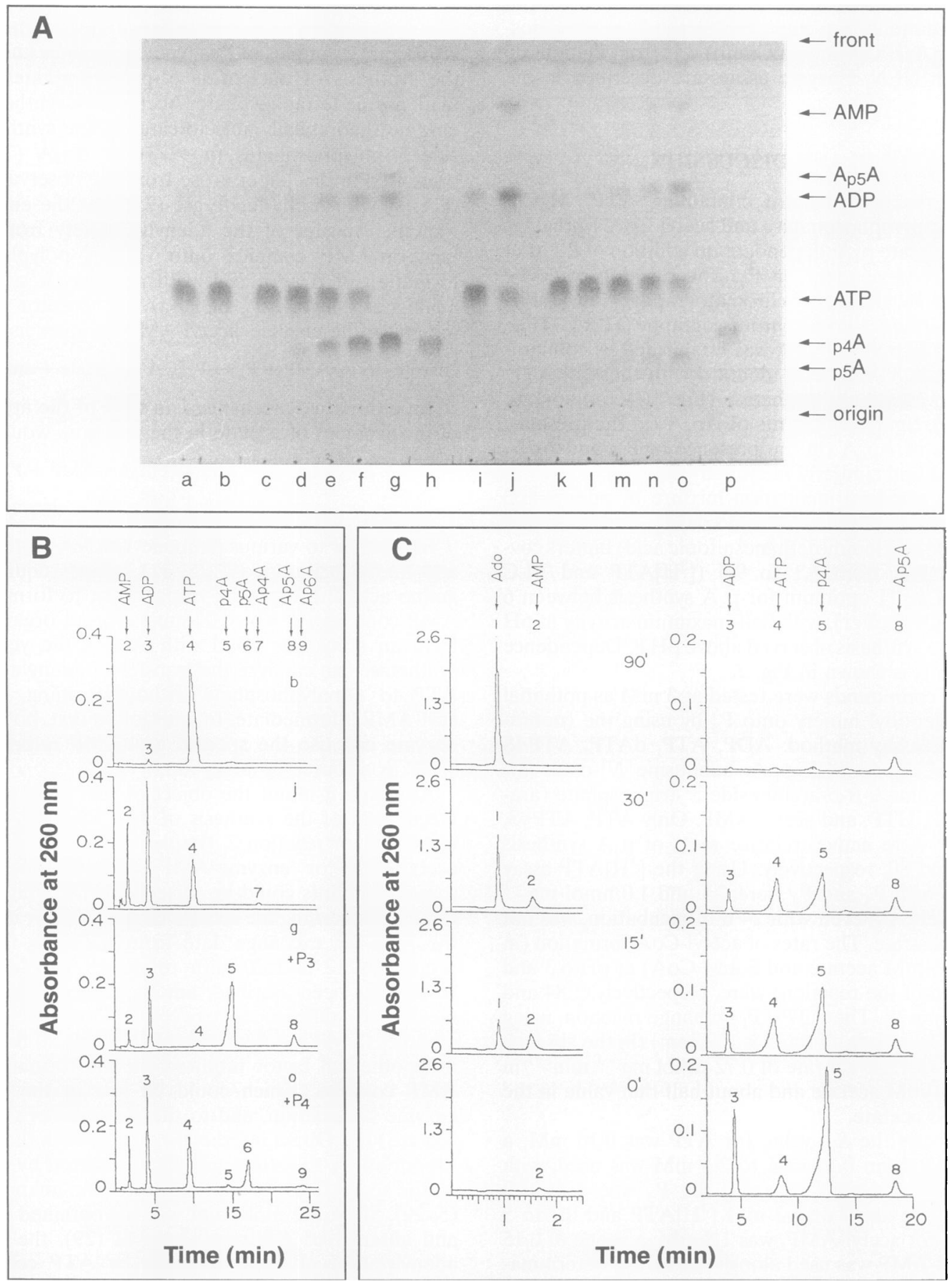

FIG. 1. Synthetic products from ATP, $\mathrm{P}_{3}$, and $\mathrm{P}_{4}$. (A) TLC. The complefe assay mixture ( $0.05 \mathrm{ml}$, final volume) contained $50 \mathrm{mM} \mathrm{MES}-\mathrm{KOH}$ (pH 6.3), $5 \mathrm{mM} \mathrm{MgCl}_{2}, 0.1 \mathrm{mM}$ dithiothreitol, $5 \mathrm{mM}$ potassium acetate, $3 \mathrm{mM}$ ATP, $0.05 \mathrm{U}$ of inorganic pyrophosphatase, $5 \mathrm{mM}$ polyphosphate, and $16 \mu \mathrm{g}$ of acetyl-CoA synthetase. Incubation was carried out at $30^{\circ} \mathrm{C}$. At the times mentioned below, 0.002 -ml aliquots were spotted on silica gel sheets containing a fluorescent indicator (Merck, Darmstadt, Germany). The chromatogram was developed for 90 min in dioxane-ammoniawater (6:1:6 by volume). This chromatographic system was specifically developed to better separate $\mathrm{p}_{4} \mathrm{~A}\left(R_{f}=0.17\right)$ and $\mathrm{p}_{5} \mathrm{~A}\left(R_{f}=0.11\right)$ from $\mathrm{ATP}$ $\left(R_{f}=0.31\right)$. The picture was taken under shortwave UV light. The lanes represent the following: a and $\mathrm{b}$, the mixture without enzyme taken after 5 and $24 \mathrm{~h}$, respectively; $\mathrm{c}$ to $\mathrm{g}$, the complete mixture containing tripolyphosphate taken after $0,1,5,10$, and $24 \mathrm{~h}$, respectively; h and p, authentic standard of $\mathrm{p}_{4} \mathrm{~A} ; \mathrm{i}$ and $\mathrm{j}$, the mixture without polyphosphate taken after 5 and $24 \mathrm{~h}$, respectively; $\mathrm{k}$ to o, complete mixture containing tetrapolyphosphate taken after $0,1,5,10$, and $24 \mathrm{~h}$, respectively. (B) HPLC. Reaction mixtures corresponding to lanes b, j, g, and o from panel A were diluted 10 -fold and analyzed by HPLC as previously described (25). (C) Effect of alkaline phosphatase. A reaction mixture with $\mathrm{P}_{3}$ (as described above) was incubated overnight at $30^{\circ} \mathrm{C}$, heated at $100^{\circ} \mathrm{C}$ for $3 \mathrm{~min}$, and centrifuged, and 0.05 -ml portions of the supernatant were treated with alkaline phosphatase $(2 \mathrm{U})$ for the indicated times and analyzed by HPLC as described in reference 25 . Ado, adenosine. 


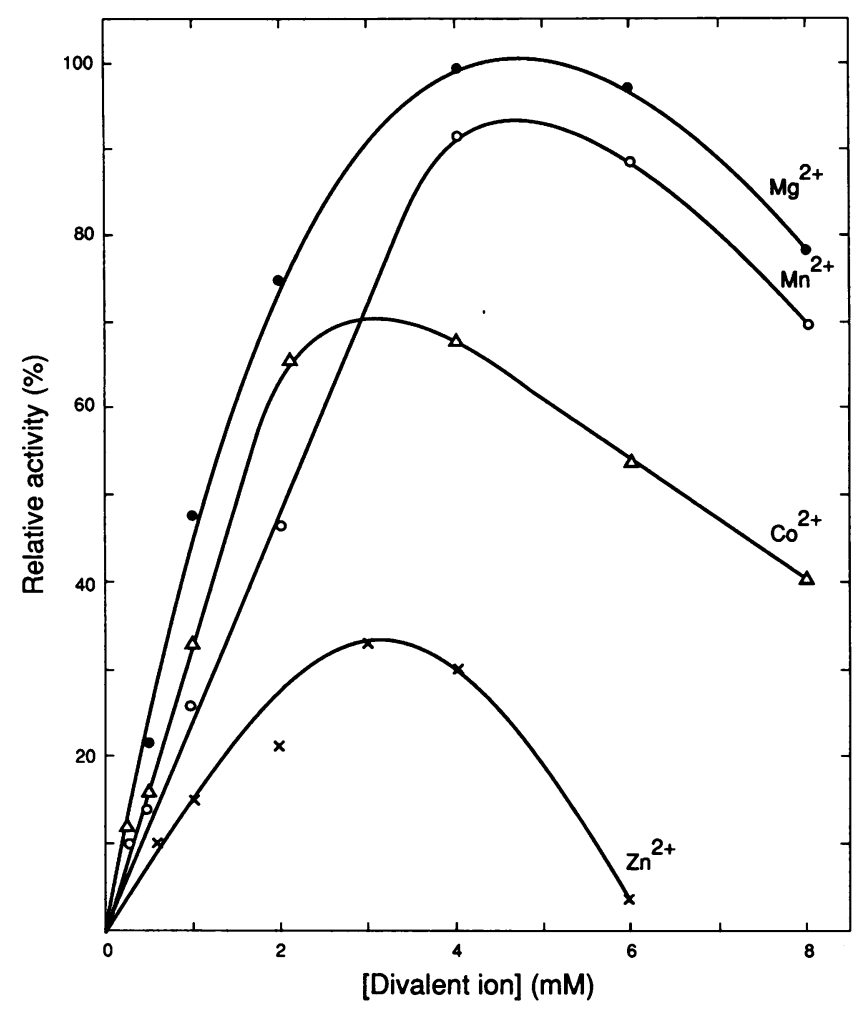

FIG. 2. Dependence of the synthesis of $\mathrm{p}_{4} \mathrm{~A}$, catalyzed by yeast acetyl-CoA synthetase, on divalent cations. The standard incubation mixture (Fig. 1) containing $\left.3 \mathrm{mM} \mathrm{[}{ }^{3} \mathrm{H}\right] \mathrm{ATP}$ was modified by substituting $5 \mathrm{mM} \mathrm{M}_{\mathrm{g}} \mathrm{Cl}_{2}$ with chloride of the indicated cation and was analyzed by TLC. Aliquots of $0.005 \mathrm{ml}$ were transferred at intervals onto silica gel sheets, $\mathrm{p}_{4} \mathrm{~A}$ or $\mathrm{p}_{5} \mathrm{~A}$ standard was added $(\sim 5 \mathrm{nmol})$, and the chromatograms were developed as described in the legend to Fig. 1. Spots corresponding to $\mathrm{p}_{4} \mathrm{~A}$ were cut, and the radioactivity was counted. In our assay conditions, 1 pmol of ATP is $4.3 \mathrm{cpm}$.

synthesis of $\mathrm{Ap}_{4} \mathrm{~A}$ is not yet clearly established. We do believe that $\mathrm{p}_{4} \mathrm{~A}$ synthesis is an intrinsic property of yeast acetyl-CoA synthetase; it was observed in four different batches of enzyme. Only one preparation (lot 42H8025, catalog no. A-5269 from Sigma) showed an insignificant capability for the synthesis of $\mathrm{p}_{4} \mathrm{~A}$. Among others, one can speculate on the following reasons for the insignificant capability: (i) mutational changes in some essential amino acids of the enzyme (a similar example for succinyl-CoA synthetase is described in reference 19), (ii) phosphorylation or dephosphorylation of the native enzyme (phosphorylation of threonyl- and seryl-tRNA synthetases) increased the $\mathrm{Ap}_{4} \mathrm{~A}$ synthesis up to six- and twofold, respectively (3), (iii) the possible occurrence of different isozymic forms, depending upon the yeast growth conditions $(13,28$, 29). In an attempt to clarify this point, the commercial preparations of acetyl-CoA synthetase used in this work were analyzed by sodium dodecyl sulfate-polyacrylamide gel electrophoresis. The enzyme from Boehringer Mannheim had a main band of $72 \mathrm{kDa}$. All samples from Sigma had two important bands of $72 \mathrm{kDa}$ (main band) and $82 \mathrm{kDa}$. The preparation from Sigma (lot 42H8025) with negligible capacity for the synthesis of $\mathrm{p}_{4} \mathrm{~A}$ presented a protein electrophoretic pattern indistinguishable from the Sigma batches which were active in the synthesis of that nucleotide.

Which enzymes contribute most to the $\mathrm{p}_{4} \mathrm{~A}$ and $\mathrm{p}_{5} \mathrm{~A}$ production observed during yeast sporulation (9) is not known.
Yeast 3-phosphoglycerate kinase catalyzes $p_{4} A$ and $p_{4} G$ synthesis at rates of about $10^{-4}$ times the rate of the transfer of a phosphate group from 1,3-bisphosphoglycerate to $\operatorname{ADP}(6,33)$. The activity of this enzyme is circa $47 \mathrm{U} / \mathrm{mg}$ of protein in crude extract (30). Aminoacyl-tRNA synthetases $(9,26,37)$ also can make $\mathrm{p}_{4} \mathrm{~A}$ and $\mathrm{p}_{5} \mathrm{~A}$. As we show here, acetyl-CoA synthetase may also contribute. Evidence for its possible role in the sporulation-related production of $\mathrm{p}_{4} \mathrm{~A}\left(\mathrm{p}_{5} \mathrm{~A}\right)$ is strengthened by the facts that (i) acetate is an inducer of sporulation (4), (ii) the level of the enzyme in yeast cells is relatively high $(0.2 \mathrm{U} / \mathrm{mg}$ of protein in crude extract (5), and (iii) yeast cells contain high levels of polyphosphates, mainly $P_{3}$ and $P_{4}(34,35)$. The possibility that acetate could stimulate $\mathrm{p}_{4} \mathrm{~A}\left(\mathrm{p}_{5} \mathrm{~A}\right)$ formation from ATP and $\mathrm{P}_{3}\left(\mathrm{P}_{4}\right)$ could then be considered as one of the reasons for the efficiency of acetate as an inducer of sporulation. Acetate has been used for that purpose, on an empirical basis, since 1916 (4). As previously stated (7), when the normal metabolic equilibria are unbalanced (as could happen in yeast cells growing in a sporulating medium), the level of such cosubstrates as specific tRNA or CoA may decrease, favoring the synthesis of $p_{4} A$ and/or $p_{5} A$ through reactions between various enzyme-X-AMP complexes and polyphosphates.

\section{ACKNOWLEDGMENTS}

This investigation was supported by Dirección General de Investigación Científica y Técnica (grant PB91/107). A.G. was a Visiting Professor of the Universidad Autónoma de Madrid. The cost of his travel to Madrid was covered by the Committee for Scientific Research (Poland) within grant 401649101.

We thank Sofía Garrido, Isabel de Diego, José Luis Sotelo, Elena Meseguer, and Javier Pérez for able technical assistance and Raul Villar (Vicerector of Universidad Autónoma de Madrid) for academic support.

\section{REFERENCES}

1. Berg, P. 1956. Acyl adenylates: an enzymatic mechanism of acetate activation. J. Biol. Chem. 222:991-1013.

2. Cameselle, J. C., M. J. Costas, M. A. G. Sillero, and A. Sillero. 1984. Two low $K_{m}$ hydrolytic activities on dinucleoside $5^{\prime}, 5^{\prime \prime \prime}$ $\mathrm{P}^{1}, \mathrm{P}^{4}$-tetraphosphates in rat liver. J. Biol. Chem. 259:2879-2885.

3. Dang, C. V., and J. A. Traugh. 1989. Phosphorylation of threonyland seryl-tRNA synthetase by cAMP-dependent protein kinase. J. Biol. Chem. 264:5861-5865.

4. Fowell, R. R. 1969. Sporulation and hybridization of yeasts, p. 303-383. In A. H. Rose and J. S. Harrison (ed.), The yeasts, vol. 1. Academic Press, London.

5. Frenkel, E. P., and R. L. Kitchens. 1977. Purification and properties of acetyl coenzyme A synthetase from bakers' yeast. J. Biol. Chem. 252:504-507.

6. García-Díaz, M., J. Canales, M. A. Günther Sillero, A. Sillero, and J. C. Cameselle. 1989. Phosphoglycerate kinase from yeast synthesizes guanosine 5'-tetraphosphate. Biochem. Int. 19:1253-1264.

7. Guranowski, A., M. A. Günther Sillero, and A. Sillero. 1990. Firefly luciferase synthesizes $\mathrm{P}^{1}, \mathrm{P}^{4}$ bis( $5^{\prime}$-adenosyl)tetraphosphate $\left(\mathrm{Ap}_{4} \mathrm{~A}\right)$ and other dinucleoside polyphosphates. FEBS Lett. 271: 215-218.

8. Ignarro, L. J., R. A. Gross, and D. M. Gross. 1976. Inhibition of mammalian soluble guanylate cyclase activity by adenosine 5 'tetraphosphate, guanosine 5 '-tetraphosphate and other nucleotides. J. Cyclic Nucleotide Res. 2:337-346.

9. Jakubowski, H. 1986. Sporulation of the yeast Saccharomyces cerevisiae is accompanied by synthesis of adenosine 5 '-tetraphosphate and adenosine 5'-pentaphosphate. Proc. Natl. Acad. Sci. USA 83:2378-2382.

10. Jencks, W. P. 1963. Preparation and properties of acyl adenylates. Methods Enzymol. 6:762-766.

11. Jetten, M. S. M., A. J. M. Stams, and A. J. B. Zehnder. 1989. Isolation and characterization of acetyl-coenzyme A synthetase from Methanothrix soehngenii. J. Bacteriol. 171:5430-5435.

12. Jones, M. E., F. Lipmann, H. Hilz, and F. Lynen. 1953. On the 
enzymatic mechanism of coenzyme A acetylation with adenosine triphosphate and acetate. J. Am. Chem. Soc. 75:3285-3286.

13. Klein, H. P., and L. Jahnke. 1971. Variations in the localization of acetyl-coenzyme A synthetase in aerobic yeast cells. J. Bacteriol. 106:596-602.

14. Kupriyanov, V. V., J. A. Ferretti, and R. S. Balaban. 1986. Muscle adenylate kinase catalyzes adenosine 5 '-tetraphosphate synthesis from ATP and ADP. Biochim. Biophys. Acta 869:107-111.

15. Lazewska, D., E. Starzyńska, and A. Guranowski. 1993. Human placental (asymmetrical) diadenosine $5^{\prime}, 5^{\prime \prime \prime}-\mathrm{P}^{1}, \mathrm{P}^{4}$-tetraphosphate hydrolase: purification to homogeneity and some properties. Protein Expression Purif. 4:45-51.

16. Lieberman, I. 1955. Identification of adenosine tetraphosphate from horse muscle. J. Am. Chem. Soc. 77:3373-3375.

17. Lobatón, C. D., C. G. Vallejo, A. Sillero, and M. A. G. Sillero. 1975. Diguanosine tetraphosphate from rat liver: activity on diadenosine tetraphosphate and inhibition by adenosine tetraphosphate. Eur. J. Biochem. 50:496-501.

18. Londesborough, J. C., and L. T. Webster, Jr. 1974. Fatty acyl-CoA synthetases, p. 469-488. In P. D. Boyer (ed.), The enzymes, vol. 10. Academic Press, New York.

19. Luo, G.-X., and J. S. Nishimura. 1992. Adenosine 5'-tetraphosphate is synthesized by histidine $\alpha 142 \rightarrow$ asparagine mutant of Escherichia coli succinyl-CoA synthetase. J. Biol. Chem. 267:9516-9520.

20. Lynen, F., and S. Ochoa. 1953. Enzymes of fatty acid metabolism. Biochim. Biophys. Acta 12:299-314.

21. Marrian, D. H. 1954. A new adenine nucleotide. Biochim. Biophys. Acta 13:278-281.

22. McElroy, W. D., M. DeLuca, and J. Travis. 1967. Molecular uniformity in biological catalyses. Science 157:150-160.

23. McLennan, A. G. (ed.). 1992. Ap4A and other dinucleoside polyphosphates. CRC Press, Boca Raton, Fla.

24. Moreno, A., C. D. Lobatón, M. A. G. Sillero, and A. Sillero. 1982. Dinucleosidetetraphosphatase from Ehrlich ascites tumour cells: inhibition by adenosine, guanosine and uridine 5 '-tetraphosphate. Int. J. Biochem. 14:629-634.

25. Ortiz, B., A. Sillero, and M. A. Günther Sillero. 1993. Specific synthesis of adenosine $\left(5^{\prime}\right)$ tetraphospho $\left(5^{\prime}\right)$ nucleoside and adenosine $\left(5^{\prime}\right)$ oligophospho $\left(5^{\prime}\right)$ adenosine $(n>4)$ catalyzed by firefly luciferase. Eur. J. Biochem. 212:263-270.

26. Plateau, P., and S. Blanquet. 1992. Synthesis of $\mathrm{Np}_{\mathrm{n}} \mathrm{N}^{\prime}(\mathrm{n}=3$ or 4) in vitro and in vivo, p. 63-79. In A. G. McLennan (ed.), Ap4A and other dinucleoside polyphosphates. CRC Press, Boca Raton, Fla.

27. Sacks, J. 1955. Adenosine pentaphosphate from commercial ATP. Biochim. Biophys. Acta 16:436.

28. Satyanarayana, T., C. H. Chervenka, and H. P. Klein. 1980 Subunit specificity of the two acetyl-CoA synthetases of yeast as revealed by an immunological approach. Biochim. Biophys. Acta 614:601-606.

29. Satyanarayana, T., and H. P. Klein. 1976. Studies on the "aerobic" acetyl-coenzyme A synthetase of Saccharomyces cerevisiae: purification, crystallization, and physical properties of the enzyme. Arch. Biochem. Biophys. 174:480-490.

30. Scopes, R. K. 1971. An improved procedure for the isolation of 3-phosphoglycerate kinase from yeast. Biochem. J. 122:89-92.

31. Sillero, M. A. G., A. Guranowski, and A. Sillero. 1991. Synthesis of dinucleoside polyphosphates catalyzed by firefly luciferase. Eur. J. Biochem. 202:507-513.

32. Small, G. D., and C. Cooper. 1966. Purification and properties of nucleoside tetraphosphate hydrolase from rabbit muscle. Biochemistry 5:14-26.

33. Small, G. D., and C. Cooper. 1966. Studies on the occurrence and biosynthesis of adenosine tetraphosphate. Biochemistry 5:26-33.

34. Solimene, R., A. M. Guerrini, and P. Donini. 1980. Levels of acid-soluble polyphosphate in growing cultures of Saccharomyces cerevisiae. J. Bacteriol. 143:710-714.

35. Urech, K., M. Duerr, T. Boller, A. Wiemken, and J. Schwencke. 1978. Localization of polyphosphate in vacuoles of Saccharomyces cerevisiae. Arch. Microbiol. 116:275-278.

36. Vallejo, C. G., M. A. G. Sillero, and A. Sillero. 1974. Diguanosinetetraphosphate guanylohydrolase in Artemia salina. Biochim. Biophys. Acta 358:117-125.

37. Zamecnik, P. C., and M. L. Stephenson. 1968. A possible regulatory site located at the gateway to protein synthesis, p. 3-16. In A San Petro, M. R. Lamborg, and F. T. Kenney (ed.), Regulatory mechanisms for protein synthesis in mammalian cells. Academic Press, Inc., New York.

38. Zamecnik, P. C., and M. L. Stephenson. 1969. Nucleoside pyrophosphate compounds related to the first step in protein synthesis, p. 276-291. In H. M. Kalckar, H. Klenow, A. Munch-Petersen, M. Ottesen, and J. H. Thaysen (ed.), Alfred Benzon Symposium I. The role of nucleotides for the function and conformation of enzymes. Elsevier Press, Munkogaard, Copenhagen. 